\title{
Mindfulness in politics and public policy Jamie Bristow
}

\author{
Current Opinion in Psychology 2019, 28:87-91 \\ https://doi.org/10.1016/j.copsyc.2018.11.003
}

\begin{abstract}
:
A key factor in the popularity of mindfulness training in public life is the conviction of grassroots advocates seeking to pass on the benefits they have experienced through personal practice. In this manner, mindfulness training has found its way into the realm of government, with parliamentary programmes seeding ambition among politicians to research and employ its transformative potential at both interpersonal and policy levels. In a high-stakes, adversarial setting, mindfulness practice helps elected representatives to cope with specific challenges, and an inquiry by the UK Mindfulness All-Party Parliamentary Group has contributed to the emergence of mindfulness training in numerous policy narratives. By developing a new kind of familiarity with their own inner lives, a growing number of politicians are finding a new way to approach political discourse, and a corresponding enthusiasm for policy that tackles society's problems at the level of the human heart and mind. Some are starting to ask whether mindfulness might be more than a targeted intervention for specific issues, and may in fact contribute to the flourishing of society more broadly marking an important development from concern with individual benefits to benefits for the whole.
\end{abstract}

The Mindfulness Initiative

https://www.themindfulnessinitiative.org.uk

jamie@mindfulnessinitiative.org.uk
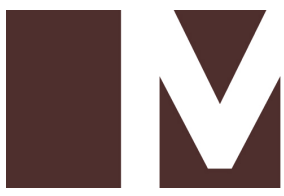

The

Mindfulness

Initiative 
Wherever mindfulness training finds popularity in public life, the necessary conditions usually include an advocate with a strong desire to share the benefits they have personally experienced through mindfulness practice $\left.{ }^{1 *}\right]$ - and an accompanying sense that those benefits will improve the functioning of their organisation or institution. In the political context, US Representative Tim Ryan (D-Ohio)', Swedish MP Anne-Marie Brodenii and British MP Chris Ruane iii all risked the ridicule of their colleagues to establish the first mindfulness initiatives within national legislatures. The most successful thus far has been in the British Parliament where, since 2013, cross-party groups from both the Houses of Commons and Lordsiv have attended eight-week mindfulness courses adapted from Mindfulness-Based Cognitive Therapy (MBCT). As of October 2018, over 200 politicians had received training, delivered by Professor Mark Williams and Chris Cullen from the Oxford Mindfulness Centre. A core group of about 20 attends a weekly drop-in class that provides continued instruction, and fosters a community of practice within Parliament. More recently, silent practice days have been offered twice a year.

Although early courses were held under a promise of strict anonymity, many participants have since spoken out publicly about the profound effects that their training has had, both personally and professionally. At a 2016 event in Parliament on 'Mindfulness and Social Change', former Government minister, and current Member of the House of Lords, Lord Alan Howarth [Labour], said: "For Members of all parties, this weekly mindfulness drop-in group is an oasis of trust and friendship - something very important in our adversarial politics. It is a very great help for my focus, energy, perspective, and sense of proportion and balance."

Tracey Crouch MP, Parliamentary Under Secretary of State for Sport and Civil Society and Conservative Minister for Loneliness, has spoken in the media about how mindfulness training helped her to tackle depression ${ }^{v}$. She is now intent on making her government department a leader in providing mindfulness training for staff.

\footnotetext{
'Time Magazine; URL: http://time.com/4585109/tim-ryan-age-of-anxiety/

ii Kvalitets Magasinet; URL: http://kvalitetsmagasinet.se/sveriges-riksdagtestar-mindfulness/

iii

Prospect

Magazine;

URL:

https://www.prospectmagazine.co.uk/politics/stop-think-breathe-vote-

mindfulness-in-parliament

iv Evening Standard; URL: https://www.standard.co.uk/news/politics/145-mpssign-up-for-8week-mindfulness-course-amid-speculation-it-could-help-withpolicymaking-a3662526.html

v Huffington Post; URL: https://www.huffingtonpost.co.uk/2015/10/20/traceycrouch-anxiety-mindfulness-mindful-nation-report-uk_n_8338048.html
} 
Following the success of the UK programme, British politicians have been invited to parliaments around the world to discuss mindfulness training vi. This has influenced a further six national legislatures (including the French ${ }^{\text {vii }}$ and Dutch viii parliaments) to start mindfulness courses. Politicians in approximately ten further countries plan similar initiatives.

In October 2017, British MPs and Lords hosted the first international 'Mindfulness in Politics Day'. 40 politicians from 14 countries attended a day of practice led by Professor Jon Kabat-Zinn, with inquiry and discussion about the implications of mindfulness for political processes and policy-makingix. On the day, Italian MP Mirko Busto summed up a critical problem in politics identified by many delegates: "any decision-maker needs a clear mind, and sometimes when you're in a stressful and aggressive environment, you end up losing the point, losing your clarity of views and doing stuff just because there is pressure." Dutch MP Esther Ouwenhand described how in the face of this difficulty, "mindfulness really enables me to stay in touch with what is most important to me: my own values."

As their personal practice has developed, British MPs and Lords from across the political spectrum have had cause to reflect on how mindfulness practice might impact the culture of political discourse for the better. Baroness Ruth Lister [Labour] remarked, "We talk about mindfulness being helpful 'out there', but what about how mindfulness could help 'in here', in Parliament? What about mindful politics more generally?". Amid growing weariness with the oldfashioned politics of antagonism dominant in Westminster, her comments hint at optimism among practitioners for mindfulness as a tool to divert energy away from bickering and toward cooperation. Conservative MP and former Education Minister Tim Loughton detects "an affinity amongst those who have been through this mindfulness course, and a rather more considered approach to exchanges of differing views" .

Some politicians note the way that the attitudes [ ${ }^{2}$ ] cultivated through mindfulness practice have begun to elicit 'different kinds of conversations'

vi Daily Mail; URL: http://www.dailymail.co.uk/news/article-

3224788/Australian-politicians-offered-free-mindfulness-meditation-classesformer-British-MP-Chris-Ruane-stop-getting-stressed.html

vii Le Parisien; URL: http://www.leparisien.fr/politique/a-l-assembleenationale-les-deputes-s-essaient-a-la-meditation-29-05-2018-

7742553.php\#xtor=AD-1481423554

viii Euro Scientist; URL: https://www.euroscientist.com/from-mindful-nation-tomindful-europe/

ix The Guardian; URL:

https://www.theguardian.com/lifeandstyle/2017/oct/13/politicians-meditatecommons-mindfulness-event

${ }^{x}$ In a speech given at the 2016 'Mind \& Matter' conference in London. 
among colleagues ${ }^{x i}$. Indeed, in certain corners of Westminster, a policy language once heavily preoccupied with metrics of economic performance increasingly admits human qualities and values as serious matters of business. Others have commented on how the tone and content of discussions they have within Parliament have shifted to 'include more of themselves'. This increased familiarity with inner experience $\left[{ }^{3}\right]$ in the act of political discourse represents a significant, if not profound shift towards less tangible insights into the human condition, that may offer a key to some of society's most pressing problems.

The potential benefits of mindfulness in the workplace and for leadership have already been discussed at length, and are increasingly being tested $\left[4 *,{ }^{5}\right]$. But a number of challenges associated with the life of an elected representative are particularly addressed by mindfulness practice, and hence seem to underpin its growing appeal:

- Attention $\left.{ }^{6}\right]$ - Legislators must absorb a colossal amount of information each day - whether from multiple briefing papers, 24-hour newsfeeds, social media, marathon debates in the Chamber or distressed constituents. Some state that improvement in their ability to concentrate helps their performance.

- Impulse control $[7,8]$ - Forever in the public eye and placed in adversarial situations, politicians often mention 'responding, not reacting' as a key learning from their course. They report improvements in self-regulation which help them to behave in ways they won't later regret.

- Kindness $\left[{ }^{9}\right]$-MPs have suggested that mindfulness practice increases their empathy with the public and constituents. Some also observe how self-care transforms their coping response when they have made public mistakes or felt overwhelmed $\left[{ }^{10}\right]$. At the Mindfulness in Politics Day, conservative Member of the Finnish Parliament and former minister Lenita Toivakka said that she hoped mindfulness would cultivate "what [she] misses in politics in Finland, and globally, and that's kindness, or 'heartfulness'".

- Meta-cognition [ "1] - A core dimension of mindfulness practice, emphasised in MBCT, involves thinking about thinking; bringing about change in perspective on thoughts and on self. Politicians regularly report that mindfulness helps them to maintain 'perspective'. They note that observing reactive thoughts as 'mental events' rather than 'the truth', enables them to identify less with obstructive beliefs. Tim Loughton's "more considered approach to exchanges of differing views" captures a related sense that participants can accept challenges to their ideas without feeling as if their identity is under attack - and thus avoiding descent into conflict. In Wales, a mindfulness course has been

xi Lord Andrew Stone in meeting of the Mindfulness All-Party Parliamentary Group, 2016. 
specifically developed to help policymakers consider their own objectivity and biases ${ }^{x i i}$, with research in progress.

Motivated by their personal experience, UK politicians began to inquire into the science of mindfulness and its potential implications for policy. In April 2014 they formed an All-Party Parliamentary Group on Mindfulness (MAPPG); a crossparty mechanism for MPs and Lords to conduct inquiries and develop policy ideas. Their administration and activities are provided by The Mindfulness Initiative; an external, non-profit policy institute.

In 2014, The MAPPG began a twelve-month inquiry into the current practice and future potential for mindfulness in public life [12**]. Eight hearings focused on the policy areas of health care, education, criminal justice and the workplace. Findings and recommendations were published in the first ever policy review of mindfulness, Mindful Nation UK [13]. Three government ministers, including the Secretary of State for Education, spoke at its launch in Parliament.

Throughout this process of inquiry, and through visits to programmes in their local constituencies, some MPs have become passionate advocates of mindfulness-based approaches within government policy. One such is Nic Dakin MP, who in a parliamentary debate on Mindfulness in Education, recently said "I was one of a host of MPs and [Lords] who did a mindfulness course in Parliament. It was transformative... These are gifts of the mind and the body... and the best time to learn these skills is at school"xiii. Clarification may be prudent here - mindfulness is best (though not always) understood as a capacity of mind - occurring naturally to a greater or lesser degree. While there's a great deal of enthusiasm for mindfulness, political advocates do recognise that innovation and research is still on-going to determine just how, when and where it's most appropriate for individuals to intentionally cultivate this capacity through training $\left[{ }^{14}\right]$.

Despite rapid growth in scientific interest in mindfulness-based approaches, the 2014 inquiry revealed a nascent evidence base (the exception being robust evidence in mental health care). Accordingly, most of the report's recommendations concerned innovation, trials and research. Encouragingly though, specific health recommendations for increasing access to MBCT through the UK National Health Service for those with recurrent depression have been acted upon, providing more people across England with an alternative to maintenance anti-depressants. Some progress has also been made in the other three policy areas, criminal justice in particular. A 'Mindfulness Steering Group'

\footnotetext{
xii School of Social and Political Science; URL: http://www.sps.ed.ac.uk/staff/sociology/rachel_howell/Mindfulness_Behavi our_Change_and_Decision_Making_Final_Report.pdf

xiii Hansard Parliament.uk; URL: https://hansard.parliament.uk/commons/2016-09-06/debates/135B46F3F51C-4AB3-933B-A05DE61BB3D8/MindfulnessInSchools
} 
has been created within the Ministry of Justice and HM Prisons and Probation Service to manage a programme of innovation and research.

The MAPPG's work signals that politicians across the party divide are becoming concerned with psychological capacities at a population level $\left.{ }^{15}\right]$. Accordingly, skills cultivated by interventions like MBCT - mindfulness, empathy, compassion, self-regulation - are finding a place in a number of emerging policy narratives. For example:

- Prevention of mental illness - mental health has rapidly climbed the UK's political agenda in recent years ${ }^{\text {xiv }}$. Policymakers increasingly accept that shifting investment towards prevention is more cost-effective than treating burgeoning clinical presentation[ $\left.{ }^{16}\right]$. Programmes that build knowledge and self-regulation capacities to support resilience and good mental health have been prioritised by the UK Secretary of State for Health ${ }^{\mathrm{x}}$, and Mindfulness-Based Interventions (MBIs) could promise 'participatory-medicine' for prevention of health problems $\left[{ }^{17}, 18,19\right]$.

- Wellbeing - Studies increasingly link certain habits and attitudes with wellbeing and life-satisfaction. For example, 'Taking Notice' (of the world and of one's emotions), has been identified as one of 'Five Ways to Wellbeing' using large data sets from the European Social Survey [ ${ }^{20}$ ]. Low levels of habitual 'taking notice' seem to be a primary factor in the UK's poor wellbeing scores (relative to other wealthy European nations).

- Technology and attention - Cultural and behavioural changes driven by digital technology are causing problems from the schoolhouse to the boardroom, as our attention is increasingly fractured, captured and monetised $[21,22]$. During a Parliamentary debate on Mindfulness in Education, Education Minister Edward Timpson MP spoke of his interest "in how mindfulness can be used to help children and young people to focus their attention...a real problem at a much younger age than ever"xvi.

- Care \& compassion - Government reviews in the wake of high-profile, regional health service scandals explicitly highlight the need for medical staff to maintain capacities of care and compassion [ $\left.{ }^{23}\right]$. The King's Fund health-policy institute provides a popular 'compassionate leadership

xiv Gov.uk The shared society: Prime Minister's speech at the Charity Commission annual meeting; URL:

https://www.gov.uk/government/speeches/the-shared-society-prime-

ministers-speech-at-the-charity-commission-annual-meeting

xv Gov.uk Matt Hancock: my priorities for the health and social care system;

URL: https://www.gov.uk/government/speeches/matt-hancock-my-prioritiesfor-the-health-and-social-care-system

xvi Hansard Parliament.uk; URL:

https://hansard.parliament.uk/commons/2016-09-06/debates/135B46F3-

F51C-4AB3-933B-A05DE61BB3D8/MindfulnessInSchools 
through mindfulness' programme xvii . The College of Policing now considers compassion and 'emotional awareness' to be core competencies, critical for crime detection and public trustxviii. The College is supporting research into mindfulness interventions for officers and staff.

- $\mathrm{C} 21^{\text {st }}$ Workplace - Since its appearance in a 2008 Government report, the concept of 'mental capital' has helped leaders and policy-makers to see that the cognitive and emotional capacities of individuals determine the health, resilience and future performance of businesses, institutions and knowledge-based economies [ $\left.{ }^{24}\right]$. Mindfulness training could develop exactly these resources $\left[{ }^{25}\right]$. Furthermore as $\mathrm{Al}$ and robotics automate jobs that don't require refined conscious awareness or emotional intelligence, working life may be refocused entirely around these uniquely human resources, with dramatic implications for education and workforce re-training [ $\left.{ }^{26}\right]$.

MBCT and other leading mindfulness programmes can develop a range of cognitive and affective skills and attitudes. While some of these might be further enhanced in combination with other interventions, many social capital innovators and some policymakers now consider mindfulness training as an important catalyst for a multiplicity of different beneficial skills and optimising practices. During discussion on how the self-regulation benefits of mindfulness could help disadvantaged citizens to engage in society, Labour MP Jon Cruddas said "I can see that [mindfulness] could act as a foundational proposition to a whole series of public policy interventions, over and above the obvious ones in terms of health".

Chris Ruane MP, Labour Co-Chair of the MAPPG, said recently, "Mindfulness helps us to respond creatively rather than react blindly, and that has an ethical dimension. Can this shift help us to act more in line with what really matters to US, moment by moment?". It is hard to imagine his words being spoken within hearing distance of The Houses of Parliament even ten years ago. Nonetheless he is now among a growing number of visionary politicians across the world who are considering whether mindfulness could in fact be a foundational capacity for a flourishing society.

xvii Kingsfund.org.uk; URL: https://www.kingsfund.org.uk/blog/2017/02/compassionate-leadershipmore-important-than-ever xviii college.police.uk; URL: https://profdev.college.police.uk/competencyvalues/

xviii Birmingham University Mental Health Policy Commission: Investing in a Resilient Generation; URL: https://www.birmingham.ac.uk/research/impact/policycommissions/mental-health/index.aspx 
The popularity of mindfulness practice is often miscast as a symptom of navelgazing individualism. In a short gestation period however, transformative benefits for politicians gave rise to an extensive policy inquiry with far-reaching results. Now we are witnessing a crucial further development: consideration of mindfulness as helpful to the whole: the whole body politic, the whole of society. Invited to comment for this article, Congressman Tim Ryan was emphatic: "Our societies are being driven by fear and anger today. We must intentionally try to reduce the influence of these things in our lives so we can think clearly and dispassionately about how we build a better future. Mindfulness is a great tool to help us get there."

\section{Acknowledgments:}

Many thanks to Joanna Cook, Chris Cullen, James Gimian and Dan Nixon for advice and suggestions in drafting this article, and to Rosie Bell for writing assistance.

Jamie Bristow is Director of the Mindfulness Initiative, a registered charity in the UK (Charity Number 1179834).

Funding this work was supported by the Lostand Foundation, Katonah, NY USA; Sankalpa via Oxford Community Foundation, Oxford, Oxfordshire UK.

References:

1'Rycroft-Malone J, Gradinger F, Griffiths HO, Crane R, Gibson A, Mercer S, et al:: Accessibility and implementation in the UK NHS services of an effective depression relapse prevention programme: learning from mindfulness-based cognitive therapy through a mixed-methods study. Health Serv Deliv Res 2017, 5:14.

${ }^{2}$ Grossman P: Mindfulness: awareness informed by an embodied ethic. Mindfulness 2015, 6:17-22

${ }^{3}$ Cooper D. Yap K, Batalha L: Mindfulness-based interventions and their effects on emotional clarity: A systematic review and meta-analysis, Journal of Affective Disorders 2018, 235:265-276

4 * Lomas T, Medina JC, Ivtzan I, Rupprecht S, Hart R \& Eiroa-Orosa FR: The impact of mindfulness on well-being and performance in the workplace: an inclusive systematic review of the empirical literature. European Journal of Work and Organizational Psychology 2017, 6:4 492-513.

${ }^{5}$ Mesmer-Magnus J, Manapragada A, Viswesvaran C \& Allen JW: Trait mindfulness at work: A meta-analysis of the personal and professional correlates of trait mindfulness, Human Performance 2017, 30:2-3, 79-98 ${ }^{6}$ Hölzel BK, Lazar SW, Gard T, Schuman-Olivier Z, Vago DR, \& Ott U: How does mindfulness meditation work? Proposing mechanisms of action from a 
conceptual and neural perspective. Perspectives on Psychological Science 2011, 6:537-559.

${ }^{7}$ Guab J, Strauss C, Bonda R, Cavanagh K: How do mindfulness-based cognitive therapy and mindfulness-based stress reduction improve mental health and wellbeing? A systematic review and meta-analysis of mediation studies, Clinical Psychology Review 2015, 37:1-12

8 Lu J. \& Huffman K, Int J: A Meta-Analysis of Correlations between Trait Mindfulness and Impulsivity: Implications for Counseling, Adv Counselling 2017, 39: 345.

9 Luberto CM, Shinday N, Song R, et al.: A Systematic Review and Metaanalysis of the Effects of Meditation on Empathy, Compassion, and Prosocial Behaviors, Mindfulness 2018, 9: 708.

10 Sinhae Cho, Hyejeen Lee, Kyung Ja Oh \& José A. Soto (2017) Mindful attention predicts greater recovery from negative emotions, but not reduced reactivity, Cognition and Emotion, 31:6, 1252-1259, DOI: 10.1080/02699931.2016.1199422

${ }^{11}$ Jankowskia T, Holasb P: Metacognitive model of mindfulness. Consciousness and Cognition 2014, 28: 64-80

${ }^{12}$ Cook J: Mindful in Westminster: The politics of meditation and the limits of neoliberal critique. HAU: Journal of Ethnographic Theory 2016 6:1, 141-161.

${ }^{13}$ Mindful Nation UK: Report by the Mindfulness All-Party Parliamentary Group (MAPPG). The Mindfulness Initiative, London; 2015. URL: http://themindfulnessinitiative.org.uk/publications/mindful-nation-uk-report.

14 * Carsley D, Khoury B \& Heath NL: Effectiveness of Mindfulness Interventions for Mental Health in Schools: a Comprehensive Meta-analysis. Mindfulness, 2018 9:693. https://doi-org.ezproxy.bangor.ac.uk/10.1007/s12671-017-0839-2 15 Pykett J., Jones R., Lilley R., Whitehead M. and Howell R,. Neuroliberalism: behavioural government in the twenty-first century. Routledge 2017.

16 Prevention concordat for better mental health. Public Health England 2018, URL: https://www.gov.uk/government/publications/prevention-concordatfor-better-mental-health-consensus-statement/prevention-concordat-forbetter-mental-health

17 Pascoe MC, Thompson DR, Jenkins ZM, Ski CF: Mindfulness mediates the physiological markers of stress: Systematic review and meta-analysis. Journal of Psychiatric Research, 2017 95: 56-178, https://doi.org/10.1016/j.jpsychires.2017.08.004.

${ }^{18}$ Barrett B, Hayney MS, Muller D, Rakel D, Brown R, et al.: Meditation or exercise for preventing acute respiratory infection (MEPARI-2): A randomized controlled trial; 2018. PLOS ONE 13(6): e0197778.

https://doi.org/10.1371/journal.pone.0197778

${ }^{19}$ Breedvelt JJF, Kandola A, Kousoulis AA, Brouwer ME, Karyotaki E, Bockting $\mathrm{CLH}$, Cuijpers $P$ : What are the effects of preventative interventions on major depressive disorder (MDD) in young adults? A systematic review and metaanalysis of randomized controlled trials. Journal of Affective Disorders, 2018. 239: 18-29, 
20 Harrison, E., Quick, A., and Abdallah, S. (eds.): Looking through the Wellbeing Kaleidoscope: Results from the European Social Survey. New Economics Foundation, 2016.

${ }^{21}$ Cook J: Paying Attention To Attention. Anthropology of this Century, 2018. http://aotcpress.com/articles/paying-attention-attention/

22 Alter A: Irresistible: The Rise of Addictive Technology and the Business of Keeping Us Hooked. Penguin Random House LLC; 2017.

${ }^{23}$ Francis R: Report of the Mid Staffordshire NHS Foundation Trust Public Inquiry Executive summary. The Mid Staffordshire NHS Foundation Trust Public Inquiry, 2013.

${ }^{24}$ Foresight Mental Capital and Wellbeing Project: Final Project report. The Government Office for Science, London; 2018.

${ }^{25}$ Good DJ, Lyddy CJ, Glomb TM, Bono JE, Brown KW, Duffy MK, Baer RA, Brewer JA, \& Lazar SW: Contemplating Mindfulness at Work: An Integrative Review. Journal of Management, 2015. 42:114-142

${ }^{26}$ Schwab K: The Fourth Industrial Revolution. World Economic Forum; 2016. 